UDC 316.42

DOI: $10.21847 / 1728-9343.2019 .1(159) .157627$

SUBBOTIN VIATCHESLAV,

National Pedagogical Dragomanov University (Kyiv, Ukraine)

e-mail:v.subbotin@ukr.net, ORCID 0000-0002-6872-8845

\title{
CONCEPTUALIZATION OF STRATEGIES FOR TRANSFORMATION OF SOCIAL DEVELOPMENT OF GLOBAL CIVILIZATION
}

In today's social philosophy, trends, concepts and models that are devoted to analyzing, researching and forecasting the development of a global society, its institutes, structures and systems are increasingly forming. Thus, on the one hand, globalization leads to economic prosperity, and on the other hand, determines the democratization of social and political life. The fact that globalization stimulates democracy is confirmed by examples where, thanks to modern information technology as producers and the intellectual, scientific, educational and industrial sectors, they have the opportunity to supply their products independently, without intermediaries, to markets, that is, markets are not currently closed by individual countries. At the same time, note that in the process of heated debates neither supporters nor representatives of globalization have not yet had a constructive vision of globalization, leading a dispute around certain aspects of the problem.

Keywords: globalization; socio-philosophical analysis; civilization approach; world system; modernization; neoliberalism; global governance; international crises; intranet nationalization; democratization; antiglobalization.

Introduction. Various socio-philosophical and globalist concepts interpret the concept of globalization differently, but it is undeniable that it is still largely perceived in relation to the processes that are taking place in the world social and economic space and which so far contribute in large measure to the growth of the gap between the poor and the poor. rich countries (Azroyants, 2002; Brzezinski, 2009; Biletsky, 2003; Bilorus, 2010; Deliagin,2003; Soros, 2004; Bello, 2016; Bhagwati, 2013; Hardt, Negri, 2006; Naisbitt, 2016, Stiglitz, 2013). That is why, along with the models, "globalism" began to emerge and acquire a rouge wave, called "anti-globalization".

Technology, economic growth, demographic factors and effective leadership form a supportive environment that will enable most people to benefit from the processes of globalization. With the support of economic liberalization through political consensus, global economic growth will spread material wealth among the general population and alleviate many of the problems associated with resources and demographic factors. In many countries the state's role is reduced to the extent that it functions as privatized or transferred to the private and the public about 'associations and global cooperation on many issues aggravated by signing various international agreements. At the same time, a smaller part of the world in Sub-Saharan Africa, the Middle East, Central Asia and South Asia, as well as in the Andean region, will not be able to take advantage of these positive changes.

With the flourishing elites, the bulk of the world's population does not benefit from globalization because population growth and resource scarcity are becoming a heavy burden for many developing countries, and migration is a major source of tension between states. Technologies are used in poor countries not to solve their problems, but are used by subversive or criminal organizations. The world economy is split into three parts: growth in developed countries, moderate or negative growth per capita in poor countries, with increasing separation from the developed world, rapid development of the shadow economy.

At the same time, both national and international governing bodies and political institutions weaken as internal conflicts intensify as a result of the collapse of hopes, with increasing inequalities and increasing social tensions.

Literature review. It is interesting that in many respects the features of modern globalism in the early twentieth century. anticipated Lenin, who wrote as follows: "the concentration of production and capital, which has reached such a high level of development, that it has created monopolies, which play a decisive role in economic life; the merger of bank capital with industry and the creation of financial capital on this basis, the financial oligarchy; the export of capital, in contrast to the export of goods, acquires an exceptional value; international monopolistic unions of capitalists dividing the world are formed; the territorial division of the land is completed by the most capitalist states" (Lenin, 1969: 346).

G. Soros believes that his principles of an open community are reflected in the democratic function of government and in a market economy, but when attempted to realize them globally, it faces difficulties in the form of national sovereignty, which was initiated by the Vespasian agreement. This should be borne in mind when starting to create a global open society, one of the ways of building which without violating national sovereignty is to provide countries with specific financial incentives that would encourage voluntary acceptance of international agreements and standards. At the same time, such a process of creating an open community should be headed by the United States (a good idea, given that all of its actions and actions on the international scene of the United States turn to their own benefit) (Soros, 2004).

Famous American researcher of Indian-born globali- 
zation, professor at Columbia University J. Bhagwati (2005) separates supporters of the anti-globalization movement into two large groups. The first is those that relate to globalization with great antipathy. Depending on different intellectual and ideological trends, they are combined with a common mentality for anti-capitalism, anti-globalism and anti-corporatism, since, in their view, globalization leads to the global spread of capitalism, and multinational companies are the main instruments of its plantation. The second is a group of critics of globalization, whose position is reduced to the condemnation of economic globalization as a cause of a number of social diseases in the modern world: poverty in poor countries and the depletion of natural resources around the world. Although anti-globalists do not stop attacks on international institutions that support globalization, but the latter are relatively strong, despite the need for reform. In the opinion of J. Bhagwati, if the first group has little to do to initiate a dialogue, the latter is capable of a dialogue on the problems of globalization (Bhagwati, 2013: 99).

According to the Nobel Prize winner in economics J. Stiglitz, for new supporters of globalization, it is a triumphant victory of American-style capitalism, and it is in itself a step forward, and therefore developing countries must accept it if economic growth and an effective fight against poverty are needed.

But globalization has not succeeded either in this struggle or in ensuring stability. In this case, "not only in the liberalization of trade, but in all other aspects of globalization, even those efforts, which seem to be the most useful goals, often have a counterproductive effect" (Stiglitz, 2013: 63)

In his view, if globalization is not something too new, then the more powerful reaction in the world to the methods that globalization is implementing is, in fact, a substantially new phenomenon. At the same time, the protesters are considering globalization in a completely different world compared to the US leadership: "The difference in opinion is so significant that one can ask: are the same phenomena protesters and those who are in power?".

The author himself asks the question - what is the phenomenon - globalization, which simultaneously causes such condemnation and approval? And it responds in the following way: "This is a closer integration of nations and peoples of the world, caused by a huge reduction in the prices of transportation and communications and the breakdown of artificial barriers to flows of goods, services, capital, knowledge and, to a lesser extent, people across borders. The globalization of education is accompanied by the creation of new institutions" (Stiglitz, 2013: 31).

According to J. Stiglitz, the powerful drivers of globalization are international corporations, which carry across borders not only goods and services, but also technologies.

In his monograph J.Stiglitz says that the three major institutions - the IMF (International Monetary Fund), the World Bank and the WTO (World Trade Organization) - are managing globalization.

The main objective of the IMF was to prevent a new world depression by exercising international influence on countries that did not make a proper contribution to supporting world aggregate demand and led their economies to recession based on the conviction that collective action at global level was needed to ensure economic stability. But, the author emphasizes, since the beginning of his existence, when the bank's goal was to provide more costly economic policies in countries - increasing public spending, lowering interest rates to stimulate the economy today the bank provides loans only when countries crash the budget deficit, raise taxes or interest rates leading to a reduction in the economy (given the current leadership of Ukraine, fulfilling the requirements of the IMF in obtaining loans, expect the growth of the economy of the country, as the leaders promise to keep you are probably a vain hope).

In turn, the World Bank in the 1980s began to draw the ideology of a free market, although most of the attention he paid to the imperfections of markets in developing countries, and the role of governments in improving the functioning of markets and reducing poverty. The bank has moved largely to broad support in the form of providing structural adjustment loans, and then after they have been approved by the IMF under the circumstances.

Thus, according to J. Stiglitz, two international financial institutions were guided by the G-7 collective will, in particular their finance ministers and heads of state treasuries, who postponed a live democratic debate on alternative strategies, guided only by the strict enforcement of conditions. As a result, the IMF did not succeed, and the policy of premature capital market liberalization contributed to global instability. At the same time, the IMF's loans and programs for a crisis country did not just stabilize the situation, but in many cases made it worse, especially for the poor.

In general, the actions of these two institutions created for many countries social and economic chaos. That is, in our opinion, if we follow the estimates of J. Stiglitz, they are the main enemies of globalization, the main idea of which is to increase the well-being of people, to overcome poverty. The globalization itself, as J. Stiglitz notes, is neither good nor bad, but for many it rests more on the relentless disaster (Stiglitz, 2013: 33-41).

The purpose of this paper is social-philosophical analysis and research of modern all directions, shapes, patterns and for the development of global processes $n$ and based on assessments of key factors of social development, demographic trends, natural resources and environment, the development of science and technology, the world economy and globalization, national and international power, future conflicts and the role of states in the context of options for a global future. To formulate estimates of trends in global governance change, which will largely change global production in the coming years, the global division of labor, the social structure of societies and enterprises around the world.

Presentation of the main material. At the global level, we now have a system that can be called global governance without a global government in which the IMF, the World Bank and the World Trade Organization are closely linked to certain financial and commercial circles, dominate the world. The time has come to change some of the rules of international economic governance, to direct globalization to improvement, when in the countries it will help to create a new global economy and sustainable growth, which will be distributed more evenly (Stiglitz, 2013: 42).

According to J. Stiglitz, the introduction of globalization in this way, as it is now, without taking into account its own mistakes, will not only not contribute to economic development but will continue to cause poverty and instability (Stiglitz, 2013: 233).

Noting that during the turbulent debate neither supporters nor representatives of globalization have a constructive vision of globalization, leading a controversy around certain aspects of the problem, J. Bhagwati wrote: "The participants of the discussion resemble the pedant Heraclitus, who, offering his house for sale, brought one brick as a sample" (Bhagwati, 2013: 102).

However, if the above remarks J. Bhagwati maybe just for a debate taking place in the western world, the Ukrainian 
and Russian researchers consistently in his many books reveal the essence of the phenomenon of globalization and especially its processes observed in the modern world with the level of economically the development of countries of the world: from "golden billion" to the poorest.

It is interesting that $\mathrm{J}$. Bhagwati began his defense of globalization in assessing the movement of anti-globalists, for which the main object of criticism is economic globalization. The author distinguished between them two groups, one of which combines anti-capitalism, antiglobalism and anti-corporatism, and the second - a position on the condemnation of economic globalization, as the causes of a number of social diseases of the modern world - impoverishment in poor countries and the depletion of natural resources. If, from the first group, the dialogue, according to J. Bhagvati, is almost unreal, then it is quite possible with another group (Bhagwati, 2013: 17).

Very interesting is the author's conclusion regarding the assessment of "unfair trade" of developed countries with poor countries, which in his view is inherent in poor countries, and that, due to incorrect generalizations of threats from globalization in the field of trade, they (threats) often exaggerate (Bhagwati, 2005: 10).

As a counterweight to the sentiment of anti-globalists, $\mathrm{J}$. Bhagwati sees increased efficiency in managing the process of globalization (in my opinion, the processes), first of all, in defining their rates, which clearly showed too much of a hasty removal of restrictions on capital movements, which accelerated the Asian financial and economic crisis of 1998 (Bhagwati, 2005: 40). Therefore, the author writes: "I am convinced that the management of globalization would be much more effective if governments, international organizations and academics (who support and advance it) would combine their efforts with NGO that is, non-governmental organizations (which are mainly criticized and opposed to it)" (Bhagwati, 2005: 49).

Cooperation with NGO is all the more important that their number has grown rapidly over the past few years and amounts to more than 2 million of these institutions in the world, with the purposeful transformation of national NGOs into transnational, global ones, taking into account not only that there is a split between NGOs in rich and poor countries, and the fact that NGOs often use methods of deliberately deceiving the public (Bhagwati, 2005: 60-67).

Explaining the problem of inequality, J. Bhagwati, firstly, believes that its severity depends on a specific society, and the country, even with an extremely large gap between the poorest and the richest people, can be stable if the profits of the winds are not "flashy luxury", but for the needs of the community; and secondly, the focus on measuring inequality, what the World Bank has done in recent years, is absurd; and thirdly, the economist should consider this problem in a concrete socio-political context (Bhagwati, 2005: 61).

Based on research of some authors, one of which is calculated by the method inequality World Bank omy nine alternative options, J. Bhagwati concludes that the claim allegedly globalization of education has led to increased poverty in developing countries, and overall global inequality, there are no grounds (Bhagwati, 2005: 91).

Touching on the use of child labor, the author writes on the basis of economic analysis, economic logic and specific data that they do not confirm the negative impact of globalization on the extent of exploitation of children (Bhagwati, 2013: 45).

One of the important problems in the context of globalization is and remains the problem of the situation of women. In this area, J. Bhagwati highlights the key role of globalization in the form of foreign expansion of Japanese corporations, which contributed to changes in the culture of Japanese behavior towards women; liberalization of foreign trade in sectors that operate under pressure from imports, helping to reduce the gap in the payment of female and male labor; Migration of women and their employment in new countries shows that, working far away from their families, they are more free both in economic and social terms than in feudal conditions in their homeland dominated by men.

According to him: "Inclusion of women in the labor force has a double benefit. On the one hand, women are given the opportunity to choose work at home or out of it. On the other hand, it is useful to the whole society, which receives direct economic benefits: because the talents and the potential for this half of the workforce come into the business" (Bhagwati, 2013: 103). However, J. Bhagwati admits that in a number of spheres of women's activities there are quite serious problems that threaten their well-being and well-being. In particular, when working in areas of export production, labor abroad, sexistry and trade in live goods.

The fact that globalization often stimulates democracy (Engdahl, 2011: 56), J. Bhagwati illustrates examples (Bhagwati, 2013: 139), where, thanks to modern information technology, farmers have the opportunity to supply their products to markets independently, without intermediaries, that is, the markets are now not beyond the boundaries of individual countries.

At the same time, on the one hand, globalization leads to economic prosperity, and, on the other hand, due to the emergence of the middle class, leads to the democratization of political life.

Based J. Linz and A. Stepan - that were used and J. Bhagwati - welfare becomes a kind of background growing demands of citizens for a more correct attitude to them and the police, in fact, authoritarian regimes (Pinochet, Franco) people put in place until economic progress and welfare became stable (Linz, Stepan, 2016: 18).

Globalization has even forced to control the principles of democracy in the WTO, which through its Secretariat officially interacts with NGO, business associations, parliamentarians and other groups. At present, the WTO has established a dispute settlement body between countries whose decisions are binding, while in the GATT, a political settlement of disputes took place behind a closed door (Bhagwati, 2013: 143).

According to J. Bhagwati, in the sphere of culture in the broad sense of the word, if the XIX century was "Pax Britanica", the XX century - "Pax Americana", despite fears that the XXI century would be "Pax Nipponika", it will again be "Pax Americana", even in the case of tough measures in many countries against the influence of American films, fast food systems, the spread of genetically modified products and the like, etc.

Another problem of globalization, which is lively in the West, is the indigenous indemnity rate, for example, US citizens against the backdrop of a massive flow of migrants from Mexico and the development of trade with poor countries.

A gravity analysis of the facts indicates that trade with the "third world" has led to wage growth. The main threat to the real wages of workers is the introduction of labor-saving technologies. Moreover, the tariffs on imports of laborintensive goods from poor countries operating in the United States (textiles, toys, etc.) reduce the real profits of the poor strata of the population, first of all, the working class.

Environmentalists have long regarded globalization as a major environmental scourge, the threat of which is, first of all, foreign trade.

The best solution is a combination of adequate 
environmental protection policies and continuous monitoring of the environment with the liberalization of international trade.

With regard to the Kyoto Protocol, by creating a "superfund" to compensate for artificial emissions into the atmosphere and the need to purchase quotas for current greenhouse gas emissions by developed countries, the provisions of this protocol could be changed to accommodate both its supporters and its opponents.

Discussing the problems associated with the actions of TNC (transnational corporations) in poor countries as a positive example can be cited the so-called "spillover effect" when local firms adopt TNC experience, raising the qualification of their workers, and adopt the tactics of TNC on exports. In general, it has been established that economic development is faster in those countries where foreign corporations operate.

At the same time, TNC play a negative role in the field of intellectual property rights protection. In fact, it is a question of paying basically poor countries for the right to use patents. Interestingly, manufacturers of pharmaceutical products and software managed to turn the WTO, which is only an organization for regulating international trade, to the agency for the collection of rent, using the WTO law to impose trade sanctions on specific countries.

In particular, J. Bhagwati believes that the "Agreement on Trade-Related Aspects of Intellectual Property Rights" (TRIPS) is concluded within the WTO in the interests of capital (Bhagwati, 2013: 252). To the detriment of TNC, trade in dangerous goods can also be attributed; goods that are considered dangerous in some countries are useless in others (for example, mixtures for newborn corporations "Nestle", "Gerber", etc., questionable products: not forbidden but deadly dangerous (for example, tobacco).

Summing up the activities of TNC, could consider them useful for poor countries through investment and employment, but the corporation can not be beyond criticism, and reasonable in the circumstances. When combining social norms, the recruitment of voluntary codes of conduct of corporations in poor countries, the mandatory national rules of different countries, it is possible to develop an optimal approach to the problem of corporate social responsibility of global corporations.

Touching on the problem of financial crises, it is possible to formulate the concept of their causes - a hasty and reckless financial liberalization of capital movements in most countries of Southeast Asia and Central and Eastern Europe, which was held (and held) often under external pressure.

As an example of positive steps to overcome the crisis, Malaysia's actions on selective monetary regulation can be cited, which allowed the country to separate the domestic financial market of the world and to stimulate the economy to lower interest rates without fear of capital flight abroad, where rates are higher.

It is strange why the leadership of our country did not take advantage of this experience, which allowed Malaysia to resume economic growth, when the economies of neighboring countries continued to fall due to the use of false IMF recipes, and, conversely, collapsed national currency.

J. Bhagwati states: " ... it seems that the times of unregulated financial capitalism have passed" (Bhagwati, 2013: 279).

This conclusion is also confirmed by the events of the financial crises of 1998 and 2008-2009, which forced the governments of many countries to actually take up the regulation of the financial market by the states.

Another problem of globalization is the growing flow of migration from poor countries to the rich. Moreover, one of the factors that stimulates the growth of migrants is the increase in the income of the population in India and China, because it allows people to pay for their travel by official means or those who organize illegal border crossing. The main reason for migration is a large difference in the standard of living of the poor and rich countries, while at the same time the growth in the rich countries of the demand for cheap labor, which is used in those areas of the national economy where the indigenous people do not want to work, as well as with the growth of demand for high qualifications specialists. According to many experts, migration is not to be limited, but to regulate.

It should be noted that to stop the migration it is not necessary to build walls, but to create economic conditions for a decent life in those countries where its main waves go.

In general, drawing a picture of globalization processes against the backdating of comparisons of mostly positive and negative features of globalization, it is possible in the future to form the scheme of effective management of it, carrying out the "red thread" idea that in the present conditions most of the problems are not created by processes of globalization, but by inadequate actions governments both developed and developing countries.

Interestingly, there is a specialization of the regions of the planet in the division of labor (Bello, 2016). So, Singapore provides additional logistics services, Italy - design, India - software, Asia - production, USA - information services, Africa - consumer goods and agriculture, South America consumer goods, Europe - high technology, Middle East oil and intellectual capital (Skejz, 2007: 27-35).

It is necessary to consider the peculiarities of the formation and operation of global corporations, which are similar to the pyramid, where the development of strategies and planning is carried out at the top with the task of meeting the demand for local markets with attempts to enter the foreign, passed to the assessment of "international corporations", where the authority is clearly distributed, and the leadership believes that foreign subdivisions of the company are better oriented in the situation in those regions where they work.

For example, Richard Scase has come up with the idea of creating "global integrated enterprises", which combines the best quality structures of "world" and "international corporations". This global integrated company will meet the regional needs and can work globally. That is, this "corporation-elephant" is capable of behaving like a "flea-entrepreneur" (Skejz, 2007: 43-44).

Such companies (Western), as a result of the aging population of developed countries, are redirected to finding talents in poor countries by employing foreign specialists, especially in countries where serious economic growth is expected.

In general, the best global integrated companies by 2020 will consist of five types of staff (In particular, see: Krugman, 2009; Naisbitt, 2016; Dreaming with BRICs: The Path to 2050; World Bank. The East Asian Miracle, 2016):

1. Corporate "celebrities" - elite personnel, which will become more specialized (crisis of non-government, mergers, acquisitions, etc.).

2. Corporate "governors", ending what the leader begins ("celebrity"), defining the company's policy, forming business plans for the divisions, providing an unhindered flow of information in all directions. Such corporate governors should stimulate and inspire employees at the local level, focusing on corporate vision and implementing all the important ideas.

But there is one danger - when the "corporate governor" is convinced that the moderator innovates moderately, is 
too bureaucratic and afraid of risk, he can easily create a competitor by becoming an entrepreneur, that is, a "leader" in his business.

3. Corporate "workers" - engineers, pharmacists, designers, chefs that promote the company's prosperity, production workers and many others, the role of each of which is insignificant, but vital in general.

4. Corporate "travelers" - temporary workers, who will be hired for a short time to achieve short-term goals. The most notable type of such a traveler is a consultant in the field of strategic management of international finance or legislation, specialists in the field of webdesign, advertising, film industry.

5. Corporate "orphans" - people who are far from a source of income: a seamstress in China, a fruit picker in Spain, and others.

In those places where globalization is most deformed, these people are not able to escape from the poverty that the employer has put them (Skejz, 2007: 46).

In this way, it becomes possible to outline the trends in global management changes that global manufacturing, the global division of labor, the social structure of societies and enterprises around the world will change in many years.

According to a sec collective monograph textbook "Globalization" (Globalizacija, 2008), the first antiglobalism as a socio-political phenomenon, proved to January 1, 1994, when Mexico began an armed uprising, the cause of which would agreement on the creation of "NAFTA" and an increase in the offensive of foreign companies to the rights of indigenous peasants, who were expelled from their eternal fertile lands. That is, it can be considered the beginning of the movement of antiglobalists. Especially since they managed to create a global network of solidarity groups through the Internet.

Indeed, the first major anti-globalization action was the protest action of American youth in November 1999 in Seattle, USA, which broke the WTO ministerial conference. Just from this statement, protest actions of anti-globalists began everywhere where meetings of heads of states, international institutions and institutions shaping global politics took place.

A few years before the book appeared, a team of scientists prepared a monograph "Globalization of the world economy and national interests", which stated that anti-globalism - a new "has not yet formed and not you scientific movement, which has a group of "globophobes" Who are not opposed to globalization in general, but against its neoliberal model and negative consequences" (Globalizacija, 2002: 36-38).

The social base of the anti-globalist movement is quite versatile, but the cornerstone of the ATTAS- France organization, formed in June 1998 around the idea of taxing financial transactions ("Tobin Tax", proposed by Professor of Yale University, Nobel Prize winner J. Tobin in the amount of $0,1 \%$ of the volumes of transactions on the world financial market) to help citizens. The following year it was adopted the Action Program, which announced the broad goal of a major restructuring of the world financial system, its institutions, and the subordination of its control of political democracy (we note that this control of the actions of international financial institutions has now been effectively established by the G-20 governments, but this required an economic gap - the financial crisis of 2008-2009).

Relying on the fact that the anti-globalization movement already has its own artisan network and that the idea of "Tobin Tax" has become the subject of government and legislative initiatives of a number of countries, the authors believe that the idea of strengthening public power and democratic control over market capitalism will be realized.
In another view, the anti-globalization movement is no less an organic source of globalization than a global financial or telecommunication community. More than that, this movement is a "built-in stabilizer" of technological and social development not only of developed countries, but of mankind as a whole (Deliagin, 2016: 206).

Eastern and Southeast Asia attract more and more attention of Western TNC to their potential growth in the number of consumers who can buy western-style goods. In these regions, as in Europe, there are more and more people who use every opportunity to come closer to the American ideals of a large amount of entertainment, a variety of food and a high level of comfort. In fact, this statement is a sign of Westernization or the Americanization of globalization.

It is very clearly seen that the USA achieved the greatest success in integrating into the Asian business community, creating 350,000 companies, partnerships and joint ventures in China (UNCTAD Handbook Statistics, 2017).

The expansion of the West to the East also manifests itself in the transfer of millions of jobs in the industry, which will create millions of jobs in the service sector.

At the same time, business leads to the spread of conflicts between people and, at the same time, to the internationalization of cultures. At the same time, if Western companies are accustomed to the fact that business culture is based on law and contracts, then in the East there is another principle, based on which personal contacts and relationships, personal trust to each other.

Considering the problems of globalization, we note that more and more people are beginning to understand the need to limit the chaotic, one-dimensional, and "wild" globalization, and to stroke forces that protest against globalization and those measures that must reduce the negative manifestations of their processes of globalization.

During the beginning of the new millennium, a number of international anti-globalization social forums took place (Henwood, 2015). In particular, the main event of the 5th Forum, which was attended by more than 150 thousand people from 136 countries representing more than 6500 organizations, was the adoption of the Manifesto, consisting of 12 points:

1. Eliminate the external debt of the South.

2. To tax international tax on transnational financial transactions, direct foreign investments, profits of TNC, arms sales and production activities that create a greenhouse effect.

3. Consistently dismantle all forms of tax, legal and so-called banking paradises.

4. Declare the right of every inhabitant of the Earth to work, social protection and retirement.

5. Develop all forms of fair trade by rejecting the rules of "free trade" established by the WTO.

6 . Guarantee the right to food sovereignty of each country through the development of family farming.

7. Prohibit any type of ownership of knowledge and wildlife (man, animal, plants), as well as any privatization of the common good of man and, above all, of water.

8. Gradually pursue all kinds of policies against racism, discrimination, sexism, xenophobia and anti-Semitism.

9. Take urgent measures to put an end to the destruction of the natural environment and the threat of climate change associated with the greenhouse effect.

10. Demand the dismantling of military bases outside national boundaries and the withdrawal of military personnel from any country other than those operating under UN authorization.

11. Guarantee the right of citizens to information through legislation that: 
- will stop the concentration of mass media in powerful communication groups;

- guarantees journalists autonomy;

- promotes a non-profit press, especially communist and alternative publications.

12. Reform and democratize international organizations, including the United Nations. In the event that the violation of international law by the United States will continue, to transfer the seat of the United Nations from New York to another country.

As you can see, the manifesto in its content has many radical requirements aimed at stopping the negative actions of globalism.

\section{Conclusions}

As a result of this study it is possible to determine that, despite large-scale globalization, regional features are more and more evident in Europe, Asia and the Americas as a result of increasing resistance to the global US dominance and its leading role in the processes of globalization, coupled with the employment of each region to solve their own economic and political issues.

At the same time, technology is spreading unevenly due to differences in the perceptions of intellectual property and the scale of the use of biotechnology, and economic integration in trade and finance, on the contrary, leads to high rates of economic growth and aggravation of regional competition. At the same time, both states and regional leadership institutions are flourishing in developed and developing countries as Governments recognize the need to address regional problems and transfer the responsibilities of global organizations to regional institutions.

In addition, it is possible to make it clear that subSaharan, Middle East, Central and South Asian regions will not succeed in seeking resources or political support.

Due to the growing need for the United States to resolve domestic issues with slowdowns and subsequent economic stagnation, economic and political tensions with Europe will intensify, and as the US withdraws its armed forces from NATO, this organization will move to a decline, and Europe will become increasingly closed and count on its own regional institutes.

In addition, the crisis of national leadership in the regions of Central and South America and the Caribbean will force the United States to focus more on these regions.

Geostrategic from mines in Asia are at with lead to long-term rivalry between the Arab states and regional and global institutions are helpless in the development of conflict there.

Given the priority of Asian countries, Europe and the two Americas, countries outside these regions will become marginalized and will in fact not have any political or financial support.

On the basis of these possible events, we note that they can be united into two groups: the first one, where the positive and negative effects of globalization are opposed, and the second - extremely competitive, but non-conflict regionalism and the transition to regional military conflicts.

In any scenario, except the first, globalization is not in from leading to widespread global cooperation in all scenarios, countries that suffer as a result of negative population growth, lack of resources and weak leadership fails to benefit from globalization.

But in all scenarios, the effectiveness of national, regional and international leadership, and at least moderate but steady economic growth, which will result in both effective social development and a certain "leveling" of the quality of education, science and technology, are vital.

\section{REFERENCES}

Azroyants, E. (2002). Globalizacija: katastrofa ili put $k$ razvitiju? Sovremennye tendencii mirovogo razvitija i politicheskie ambicii. "Novyj vek" Publishing, Moscow, 416 p. (In Russian).

Bello, W. (2016). U.S. Foreign Policy? Donald Trump. (How the $\mathrm{CIA}$, bad trade deals, and wanton military intervention caused the social crises that gave us the Donald). Foreign Policy In Focus, January 6, Retrieved from http://fpif.org/ultimate-blowback-u-sforeign-policy-donald-trump (In English).

Bhagvati, Dzh. (2005). V zatshitu globalizatsii. Trans. from English. Ladomir Publishing, Moscow, 448 p. (In Russian).

Bhagwati, J. (2013). Why Growth Matters: How Economic Growth in India Reduced Poverty and the Lessons for Other Developing Countries. PublicAffairs, New York, 280 p. (In English).

Brzezinski, Zb. (2009). Velikaja shahmatnaja doska. Trans. from English. Mezhdunarodnye otnoshenija, Moscow, 478 p. (In Russian).

Biletsky, V. S. (2003). Zagrozi globalizmu. In: Socialnye, ekonomicheskie, politicheskie i psihologicheskie posledstvija globalizacii $v$ sovremennom obtchestve: materiali Vseukr. nauch.-prakt. konf., 03.13-14.2003, Donetsk: 23-27. (In Ukrainian).

Bilorus, O. (2010). Globalistyka - nova syntetychna nauka. Visnyk Natsionalnoyi akademiyi nauk Ukrayiny. № 3: 17-26. (In Ukrainian).

Deliagin, M. G. (2016). Mirovoj krizis: Obshaja teorija globalizacii. (6 Ed.), INFRA-M, Moscow, 768 p. (In Russian).

Dreaming with BRICs: The Path to 2050. The Goldman Sachs Group Inc. Retrieved from http://www2.goldmansachs.com/idecs/ brics/book/99-dreaming.pdf (In English).

Engdahl, W. (2011). A century of war. Anglo-American oil politics and the New World Order. Dinges \& Frick, Wiesbaden: 356 p. (In English).

Mikhaylov, V. A. and Buyanov, V. S. (ed.) (2008). Globalizacija. RAGS Publishing, Moscow, 544 p. (In Russian).

Globalizacija mirovogo khosiaystva i nacionalnyje interesy. (2002). Ekonomicheskij fakultet MGU, TEIS, 631 p. (In Russian).

Hardt, M. \& Negri, A. (2006). Multitude: War and Democracy in the Age of Empire. The Penguin Press, New York: 450 p. (In English).

Hardt, M. (2000). Empire. Cambridge, MA: Harvard University Press, 478 p. (In English).

Henwood, D. (2015). Wall Street. How It Works and for Whom. Verso. London and New York: 272 p. (In English).

Krugman, P. (2009). The Conscience of a Liberal. W. W. Norton \& Company, New York: 352 p. (In English)

Lenin, V. I. (1969). Imperializm, kak vysshaja stadija kapitalizma. In: Polnoe sobranie sochineniy: v 55 t. (5 ed.). Vol.27. Politizdat, Moscow: 299-426. (In Russian).

Linz, J. (2016). Problems of Democratic Transition and Consolidation. Baltimore (Md.), London: The John Hopkins Univ. Press., 504 p. (In English).

Martin, G. (2001). Zapadnia globalizatsii. ALPINA, Moscow, 335 p. (In Russian).

Naisbitt, J. (2016). Global Paradox. Avon Books, 392 p. (In English)

Skejz, R. (2007). Globalnyi peredel: kak perestroit sebia $i$ svoyu kompaniyu. Vershina, Moscow, 208 p. (In Russian).

Soros, G. (1999). Krizis mirovogo kapitalizma. Trans. from English. Moscow, 262 p. (In Russian).

Soros, G. (2004). O globalizatsii. Trans. from English. EKSMO, Moscow, 220 p. (In Russian).

Stiglitz, J. E. (2013). Globalization and Its Discontents. W. W. Norton \& Company, New York: 304 p. (In English).

UNCTAD Handbook Statistics (2017). New York and Geneva: United Nations Organisation, 87 p. (In English).

World Bank (2016). The East Asian Miracle: Economic Growth and Public Policy. Washington: Oxford University Press, 120 p. (In English).

ISSN 1728-9343 (Print) ISSN 2411-3093 (Online) 


\section{LIST OF REFERENCE LINKS}

Азроянц Э. Глобализация: катастрофа или путь к развитию? Современные тенденции мирового развития и политические амбиции. Москва: ИД "Новый век", 2002. 416 с.

Бжезинский 3б. Великая шахматная доска (пер. с англ.). Москва: Международные отношения, 2009. 478 с.

Білецький В. С. Загрози глобалізму. Социальные, экономические, политические и психологические последствия глобализации в современном обществе: материали Всеукр. науч.-практ. конфр., 13-14 марта 2003 г., Донецк, 2003. C. 23-27.

Білорус О., Власов В. Глобалістика - нова синтетична наука. Вісник Національної академії наук України. 2010. № 3. C.17-26.

Бхагвати Дж. В защиту глобализации. Москва: Ладомир, 2005. 448 c.

Глобализация / под общ. ред. В. А. Михайлова и В. С. Буянова. Москва: Изд-во РАГС, 2008. 544 с.

Глобализация мирового хозяйства и национальные интересы. Москва: Экономический фракультет МГУ, ТЕИС, 2002. C. $36-38$.

Делягин М. Г. Мировой кризис: Общая теория глобализации. (6-е изд., перераб. и доп.). Москва: ИНФРА-М, 2016. $768 \mathrm{c.}$.

Ленин В. И. Империализм, как высшая стадия капитализма. Ленин В.И. Полное собрание сочинений: в $55 \mathrm{~m}$. (5 изд.) Москва: Политиздат, 1969. Т. 27. С. 299-426.

Мартин Г. Западня глобализации. Москва: АЛЬПИНА, 2001. $335 \mathrm{c}$.

Скейз Р. Глобальный передел: как перестроить себя и свою компанию (пер. с англ.). Москва: Вершина, 2007. 208 с.

Сорос Дж. Кризис мирового капитализма (пер. с англ.). Москва, 1999. 262 с.
Сорос Дж. О глобализации (пер. с англ.). Москва: ЭКСМО, 2004. 220 c.

Bello W. U.S. Foreign Policy? Donald Trump.(How the CIA, bad trade deals, and wanton military intervention caused the social crises that gave us the Donald). Foreign Policy In Focus, January 6, 2016. URL: http://fpif.org/ultimate-blowback-u-s-foreign-policydonald-trump (дата звернення 10.12.2018).

Bhagwati J. Why Growth Matters: How Economic Growth in India Reduced Poverty and the Lessons for Other Developing Countries. New York: Public Affairs, 2013. 280 p.

Dreaming with BRICs: The Path to 2050. The Goldman Sachs Group Inc. URL: http://www2.goldmansachs.com/idecs/brics/ book/99-dreaming.pdf (дата звернення 16.12.2018).

Engdahl W. A century of war. Anglo-American oil politics and the New World Order. Wiesbaden: Dinges \& Frick, 2011. 356 p.

Hardt M. Empire. Cambridge, MA: Harvard University Press, 2000. 478 p.

Hardt M. \& Negri A. Multitude: War and Democracy in the Age of Empire. New York: The Penguin Press, 2006. 450 p.

Henwood D. Wall Street. How It Works and for Whom. London and New York: Verso, 2015. 372 p.

Krugman P. The Conscience of a Liberal. New York: W.W. Norton \& Company, 2009. $352 \mathrm{p}$.

Linz J., Stepan A. Problems of Democratic Transition and Consolidation. Baltimore (Md.), London: The John Hopkins Univ. Press., 2016. 504 p.

Naisbitt J. Global Paradox. Avon Books, 2016. 392 p.

Stiglitz J. E. Globalization and Its Discontents. New York: W.W. Norton \& Company, 2013. 304 p.

UNCTAD Handbook Statistics. New York and Geneva: United Nations Organisation, 2017. $87 \mathrm{p}$.

World Bank. The East Asian Miracle: Economic Growth and Public Policy. Washington: Oxford University Press, 2016. 120 p.

Субботін В'ячеслав,

Національний педагогічний університет імені М. П. Драгоманова (м. Київ, Україна)

e-mail:v.subbotin@ukr.net,ORCID0000-0002-6872-8845

\section{КОНЦЕПТУАЛІЗАЦІЯ СТРАТЕГІЙ ТРАНСФОРМАЦІї СУСПІЛЬНОГО РОЗВИТКУ ГЛОБАЛЬНОїЦИВІЛІЗАЦІї}

У сучасній соціальній філософії все активніше формується напрям, концепції та моделі якого присвячені аналізу, дослідженню та прогнозуванню розвитку глобального суспільства, його інститутів, структур та систем. При цьому, з одного боку, глобалізація веде до економічного процвітання, а 3 іншого, зумовлює демократизацію суспільного та політичного життя. Те, що глобалізація стимулює демократію, підтверджується прикладами, де завдяки сучасним інформаційним технологіям як виробники інтелектуальної, наукової, освітньої сфер, так і виробничих секторів, мають можливість самостійно, без посередників постачати свої товари на ринки, тобто ринки нині не обмежені кордонами окремих країн. Ринкові фундаменталісти вірять у те, що суспільний інтерес дотримується якнайповніше у тому випадку, коли за кожною особою визнається право переслідувати свої особисті інтереси. При цьому ринковий фундаменталізм не є протилежністю його концепції відкритої спільноти. Він, швидше, гіпертрофрія одного з їі (концепції) аспектів. Водночас бізнес призводить до поширення конфліктів між людьми та інтернаціоналізації культур. При цьому, якщо західні компанії звикли до того, що культура бізнесу заснована на законах і контрактах, то на Сході діють інші принципи, основою яких $є$ особисті контакти і взаємовідносини, особиста довіра один до одного. Водночас зазначимо, що в процесі бурхливих дебатів ані прибічники, ані противники глобалізації поки що не мають достатньо конструктивного бачення глобалізації, ведучи суперечку навколо окремих аспектів проблеми.

Ключові слова: глобалізація; соціально-фрілософрський аналіз; цивілізаційний підхід; світ-система; модернізація; неолібералізм; глобальне управління; міжнародні кризи; інтернаціоналізація; демократизація; антиглобалізм.

(c) Subbotin Viatcheslav

Надійшла до редакції: 17.12.2018

Прийнята до друку: 14.02.2019 